\title{
Synthesis, Thermolysis, Photolysis and Antimicrobial Evaluation of some Novel Semicarbazones and Thiosemicarbazones Derived from 3-Methyl-2- benzothiazolinone Hydrazone.
}

\section{Hisham Abdallah A. Yosef * and Nabila M. Ibrahim}

Department of Organometallic and Organometalloid

Chemistry, National Research Centre, El-Behouth Street, P.O. 12622, Dokki, Giza, Egypt.

\begin{abstract}
REACTION of 3-methyl-2-benzothiazolinone hydrazone (1) with R some selected isocyanate and isothiocyanate reagents $2 \mathrm{a}-\mathrm{j}$ gave the respective semicarbazones and thiosemicarbazones $3 \mathrm{a}-\mathrm{j}$. Thermolysis of compound $3 \mathrm{a}$ under reduced pressure gave $\mathrm{N}, \mathrm{N}$-diethylurea (4) in addition to 1,2-bis(3-methylbenzo[d]thiazol$2(3 \mathrm{H})$-ylidene)hydrazine (5). Compound 3a was almost quantitatively recovered upon its exposure to sunlight in methanol for 60 days. Elementary and spectroscopic measurements (IR, ${ }^{1} \mathrm{H}$ NMR, ${ }^{13} \mathrm{C} N \mathrm{NMR}$, MS) are in good accord with the structures postulated for the new compounds. The single crystal X-ray crystallographic analysis of $3 \mathrm{f}$ was given and its data were discussed. The synthesized compounds $3 \mathrm{a}-$ $\mathrm{j}$ as well as the hydrazone 1 were screened for their antibacterial properties against Bacillus subtilis $\left(G^{+}\right)$, Escherichia coli $\left(\mathrm{G}^{-}\right)$, Pseudomonas aeruginosa $\left(\mathrm{G}^{-}\right)$and Staphylococcus aureus $\left(\mathrm{G}^{+}\right)$and for their antifungal properties against Aspergillus flavus and Candida albicans. Some of the tested compounds showed an activity against the four bacterial strains where their order of activity was found to be $1>$ $3 \mathrm{~g}>3 \mathrm{j}>3 \mathrm{i}>3 \mathrm{e}>3 \mathrm{~h}>3 \mathrm{a}$. The $\mathrm{MIC}_{90}$ value of compound 1 against $P$. aeruginosa was $9 \mathrm{mg} / \mathrm{ml}$. On the other hand only compound 1 showed a significant activity against $A$. flavus fungal species where it recorded an inhibition zone diameter value $(16 \mathrm{~mm} / \mathrm{mg})$ which is very near to that of the standard drug, amphotericin B $(17 \mathrm{~mm} / \mathrm{mg})$. However, the $C$. albicans was found to be insensitive to all of the investigated compounds.
\end{abstract}

Keywords: 3-Methyl-2-benzothiazolinone hydrazone, Semicarbazones, Thiosemicarbazones, Azines, X-ray crystallographic analysis, Antimicrobial activity.

Antimicrobials are one of a very important category of drugs which are prescribed right from simple infections to the serious diseases. But the microbial resistance towards the drug creates a very serious problem where many drugs which were very effective before are now useless. Moreover, the toxic effects produced by these antibiotics are also reducing their significance. ${ }^{(1,2)}$ So the need for new antimicrobials is always there. Some of most interesting classes of

\footnotetext{
* Correspondence: hishamayosef@yahoo.com
} 
compounds, in organic chemistry, are the semicarbazones and thiosemicarbazones due to their significant antibacterial and antifungal activities ${ }^{(3-6)}$. For example, nitrofural (other names include: nitrofurazone and furacilin; trade name: Furacin) (Fig. 1) is a semicarbazone derivative which is known to have a bactericidal activity. Nitrofural is used topically for skin infections where it was found to be effective on the most of infectious microorganisms ${ }^{(7)}$.<smiles>NC(=O)N/N=C/c1ccc([N+](=O)[O-])o1</smiles>

Fig. 1. Nitrofural (Furacin).

Moreover, recent works have revealed that semicarbazones exhibited many other pharmacological activities including anticonvulsant ${ }^{(8-10)}$, anti-tubercular ${ }^{(11)}$, antitumor, ${ }^{(12)}$ anticancer ${ }^{(13)}$, analgesic and anti-inflammatory activities ${ }^{(14)}$. On the other hand, benzothiazole derivatives showed diverse pharmacological potentialities such as antimicrobial $^{(15-17)}$, antiviral ${ }^{(18)}$, anticancer ${ }^{(19)}$, antitumor $^{(20)}$, anthelmintic $^{(21)}$, anti-inflammatory ${ }^{(22)}$ and anti-diabetic ${ }^{(22,23)}$ activities. Therefore, such wide range of activities, including semicarbazones and benzothiazoles, has motivated us to synthesize new compounds incorporating both moieties in one structure and evaluating their antimicrobial activity.

\section{Results and Discussion}

\section{Chemistry}

Synthesis of the semicarbazones and thiosemicarbazones $3 a-j$

The semicarbazones 3a-e were synthesized by reacting 3-methyl-2benzothiazolinone hydrazone (1) with the appropriate isocyanate reagent $2 \mathrm{a}-\mathrm{e}$ in dry 1,4-dioxane at room temperature (Scheme 1).

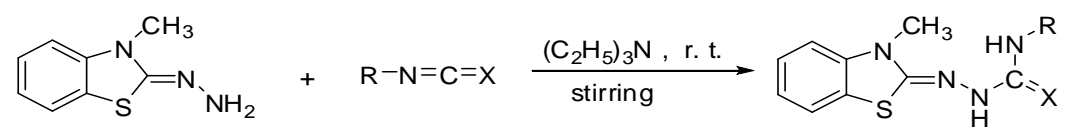

1

$\begin{array}{clc}\mathbf{2} \text { and 3 } & \mathbf{R} & \mathbf{X} \\ \mathbf{a} & \mathrm{C}_{2} \mathrm{H}_{5} & \mathrm{O} \\ \mathbf{b} & \mathrm{C}\left(\mathrm{CH}_{3}\right)_{3} & \mathrm{O} \\ \mathbf{c} & 4-\mathrm{Cl}-\mathrm{C}_{6} \mathrm{H}_{4} & \mathrm{O} \\ \mathbf{d} & 3,4-(\mathrm{Cl})_{2}-\mathrm{C}_{6} \mathrm{H}_{3} & \mathrm{O} \\ \mathbf{e} & 4-\mathrm{NO}_{2}-\mathrm{C}_{6} \mathrm{H}_{4} & \mathrm{O} \\ \mathbf{f} & \mathrm{C}_{2} \mathrm{H}_{5} & \mathrm{~S} \\ \mathbf{g} & \mathrm{C}_{6} \mathrm{H}_{5} & \mathrm{~S} \\ \mathbf{h} & \mathrm{C}_{6} \mathrm{H}_{5}-(\mathrm{CO}) & \mathrm{S} \\ \mathbf{i} & 4-\left(\mathrm{CH}_{3} \mathrm{O}\right)-\mathrm{C}_{6} \mathrm{H}_{4} & \mathrm{~S} \\ \mathbf{j} & 2-\mathrm{CH}_{3}-\mathrm{C}_{6} \mathrm{H}_{4} & \mathrm{~S}\end{array}$

Scheme 1. Synthesis of the semicarbazones and thiosemicarbazones $3 a-j$. 
Compound 3a, namely, N-ethyl-2-(3-methylbenzo[d]thiazol-2(3H) ylidene) hydrazine-carboxamide, taken as an example, was given the assigned structure due to the following reasons

a) Compatible elementary microanalysis corresponded to a molecular formula of $\mathrm{C}_{11} \mathrm{H}_{14} \mathrm{~N}_{4} \mathrm{OS}$ (250.32).

b) The IR spectrum $\left(\mathrm{KBr}, v_{\max }, \mathrm{cm}^{-1}\right)$ of $\mathbf{3 a}$ showed strong absorption bands at $3369(\mathrm{~N}-\mathrm{H}), 3130(\mathrm{C}-\mathrm{H}$, aromatic $), 2962(\mathrm{C}-\mathrm{H}$, aliphatic $), 1653(\mathrm{C}=\mathrm{O})$, $1610(\mathrm{C}=\mathrm{N}$, exocyclic) and $1585(\mathrm{C}=\mathrm{C}$, aromatic $)$.

c) The ${ }^{1} \mathrm{H}$ NMR spectrum (500 MHz, DMSO- $\mathrm{d}_{6}, \delta \mathrm{ppm}$ ) of 3a showed a triplet $(3 \mathrm{H})$ at $1.02 \mathrm{ppm}$ and a quartet $(2 \mathrm{H})$ at $3.11 \mathrm{ppm}$, both with $\mathrm{J}_{\mathrm{HH}}=6.9 \mathrm{~Hz}$, due to the protons of $-\mathrm{CH}_{3}$ and $-\mathrm{CH}_{2}$ groups, respectively, of the ethyl group. The methyl group on the nitrogen atom of the fused thiazole ring appeared as a singlet at $\delta 3.46 \mathrm{ppm}$. The four aromatic protons of the benzothiazole ring appeared as two doublets $\left(\mathrm{J}_{\mathrm{HH}}=7.6 \mathrm{~Hz}\right)$ at 7.15 and $7.53 \mathrm{ppm}$ and as two triplets $\left(\mathrm{J}_{\mathrm{HH}}=7.6 \mathrm{~Hz}\right)$ at 7.01 and $7.28 \mathrm{ppm}$. The spectrum revealed also the presence of two singlet signals at $\delta 6.40$ and $8.21 \mathrm{ppm}$ due to the two $\mathrm{D}_{2} \mathrm{O}$ exchangeable protons on nitrogen atoms.

d) The ${ }^{13} \mathrm{C}$ NMR spectrum (125 MHz, DMSO- $d_{6}, \delta \mathrm{ppm}$ ) of semicarbazone 3a, exhibited three signals in the region of $s p^{3}$ carbons at $16.29,31.00$ and 34.50 ppm due to the carbon atoms of groups $\left(-\mathrm{CH}_{3}\right),\left(\mathrm{N}-\mathrm{CH}_{3}\right)$ and $\left(-\mathrm{CH}_{2}-\right)$, respectively. The two signals that appeared at $\delta 158.71$ and $160.96 \mathrm{ppm}$ are attributed to $\boldsymbol{C}=\mathrm{O}$ and $\boldsymbol{C}=\mathrm{N}$ groups, respectively. Carbon atoms of the fused benzene ring appeared as six signals at 109.78, 121.52, 122.50, 122.83, 127.06 and $141.77 \mathrm{ppm}$.

e) The mass spectrum (MS: m/z, (\%)) of 3a recorded the molecular ion peak $\left[\mathrm{M}^{+}\right]$at $\mathrm{m} / \mathrm{z} 250(20 \%)$ (Scheme 2). Loss of a neutral ethyl amine molecule from $\left[\mathrm{M}^{+}\right]$yields the radical cation a at $\mathrm{m} / \mathrm{z} 205(42 \%)$. Meanwhile, loss of an ethyl isocyanate molecule from $\left[\mathrm{M}^{+}\right]$produces the radical cation $\mathbf{b}$ of the starting hydrazone at $\mathrm{m} / \mathrm{z} 179(37 \%)$. Cleavage of $\left[\mathrm{M}^{+}\right]$, ion $\mathbf{a}$ and / or ion $\mathbf{b}$ at axis $\mathbf{x}$ can afford cation $\mathbf{c}$ at $\mathrm{m} / \mathrm{z} 163(47 \%)$. The prominent ion peak present at $\mathrm{m} / \mathrm{z} 108(20 \%)$ coincides with the episulphide species d which could result from cleavage of the thiazole ring under electron bombardment. The latter ion can add a hydrogen radical to give cation e at m/z $109(65 \%)$ (Scheme 2).

Similarly, the reaction of the isothiocyanate reagents $2 \mathrm{f}-\mathrm{j}$ with hydrazone 1 in 1,4-dioxane gave the corresponding thiosemicarbazone derivatives $3 \mathrm{f}-\mathrm{j}$ (Scheme 1). The IR spectrum $\left(\mathrm{KBr}, v_{\max }\right)$ of N-ethyl-2-(3-methylbenzo[d]thiazol-2(3H)ylidene)hydrazinecarbothioamide (3f), as an example, showed a strong absorption band at $1160 \mathrm{~cm}^{-1}$ due to the $\mathrm{C}=\mathrm{S}$ group. The spectrum recorded also bands at $3288(\mathrm{~N}-\mathrm{H}), 3093(\mathrm{C}-\mathrm{H}$, aromatic), $2927(\mathrm{C}-\mathrm{H}$, aliphatic), 1599 $(\mathrm{C}=\mathrm{N}), 1535\left(\mathrm{C}=\mathrm{C}\right.$, aromatic) $\mathrm{cm}^{-1}$. The ${ }^{1} \mathrm{H}$ NMR spectrum $(500 \mathrm{MHz}$, DMSO$d_{6}$ ) recorded three signals at $\delta 1.10\left(\mathrm{t}, \mathrm{J}_{\mathrm{HH}}=9.0 \mathrm{~Hz}, 3 \mathrm{H}\right), 3.45(\mathrm{~s}, 3 \mathrm{H})$ and $3.52(\mathrm{q}$, $\left.\mathrm{J}_{\mathrm{HH}}=9.0 \mathrm{~Hz}, 2 \mathrm{H}\right) \mathrm{ppm}$ due to proton of the $-\mathrm{CH}_{3}, \mathrm{~N}-\mathrm{CH}_{3}$ and $-\mathrm{CH}_{2^{-}}$groups, 
respectively. The signals due to the four aromatic protons appeared at $\delta 7.09(\mathrm{t}$, $\left.\mathrm{J}_{\mathrm{HH}}=6.9 \mathrm{~Hz}\right), 7.20\left(\mathrm{~d}, \mathrm{~J}_{\mathrm{HH}}=6.9 \mathrm{~Hz}\right), 7.35\left(\mathrm{t}, \mathrm{J}_{\mathrm{HH}}=6.9 \mathrm{~Hz}\right)$ and $7.58\left(\mathrm{~d}, \mathrm{~J}_{\mathrm{HH}}=6.9\right.$ $\mathrm{Hz}) \mathrm{ppm}$. The two protons on nitrogen atoms appeared as two singlets at $\delta 7.75(1 \mathrm{H})$ and $9.80(1 \mathrm{H}) \mathrm{ppm}$ which disappeared upon running the ${ }^{1} \mathrm{H}$ NMR experiment in presence of $\mathrm{D}_{2} \mathrm{O}$. The ${ }^{13} \mathrm{C}$ NMR spectrum (125 MHz, DMSO- $d_{6}$ ) of $3 \mathrm{f}$ disclosed a signal at $\delta 178.41 \mathrm{ppm}$ due to the carbon atom of $C=\mathrm{S}$ bond. ${ }^{(24)}$ The signals due to the two carbon atoms of the ethyl group appeared at $\delta 15.33\left(-\mathrm{CH}_{3}\right)$ and $38.78\left(-\mathrm{CH}_{2}-\right)$ $\mathrm{ppm}$. The spectrum revealed also signals at $\delta 31.21\left(\mathrm{~N}_{-} \mathrm{CH}_{3}\right), 110.21,121.97,122.37$, 122.91, 127.22, 141.41 (aromatic carbons), $162.18(C=\mathrm{N})$ ppm. The molecular weight determination (MS: $70 \mathrm{eV}$, EI) of $3 \mathrm{f}$ has recorded the molecular ion peak at $\mathrm{m} / \mathrm{z} 266(83 \%)$ which corresponded to a molecular formula of $\mathrm{C}_{11} \mathrm{H}_{14} \mathrm{~N}_{4} \mathrm{~S}_{2}$. Moreover, the structure of compound $3 \mathrm{f}$ is confirmed by the single crystal X-ray crystallography. Figure 2 showed an ORTEP overview of 3 f. The crystal structural data, selected bond lengths, bond angels and torsion angels of $3 \mathrm{f}$ are represented in Tables 1, 2, 3 and 4, respectively.

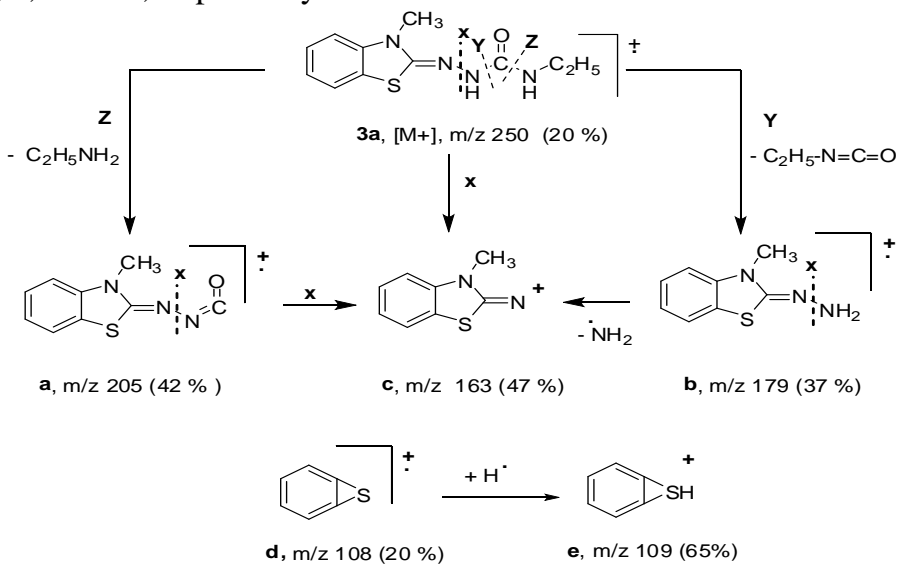

Scheme 2. Mass spectrum of compound 3a.

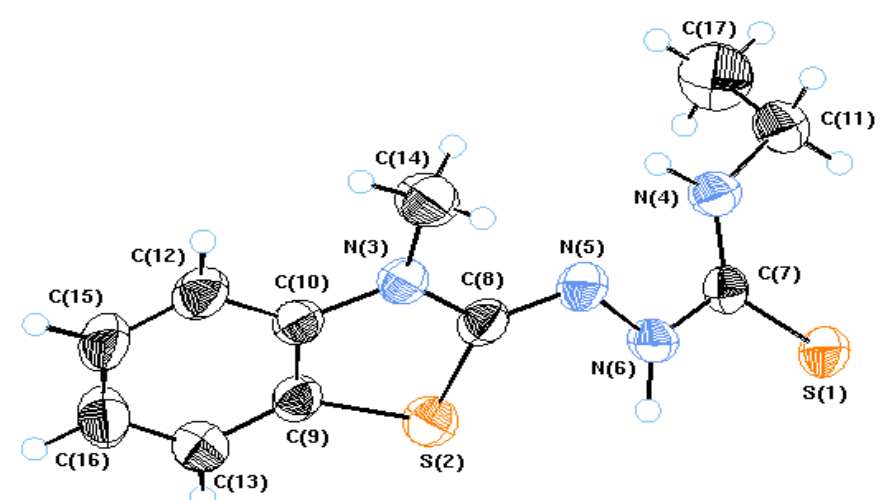

Fig. 2. ORTEP overview of compound $3 f$.

Egypt. J. Chem. 59, No. 5 (2016) 
TABLE 1. Crystal structure and data refinement of compound $3 \mathrm{f}$.

\begin{tabular}{|c|c|}
\hline Empirical Formula & $\mathrm{C}_{11} \mathrm{H}_{14} \mathrm{~N}_{4} \mathrm{~S}_{2}$ \\
\hline Formula Weight & 266.389 \\
\hline Crystal System / Space Group & Monoclinic / $\mathrm{P} 2{ }_{1} / \mathrm{c}$ \\
\hline a / $\AA$ & $12.7989(5)$ \\
\hline b / $\AA$ & $8.4166(4)$ \\
\hline $\mathrm{c} / \mathrm{A}$ & $14.0071(12)$ \\
\hline$\alpha /{ }^{\circ}$ & 90.00 \\
\hline$\beta /{ }^{\circ}$ & 12. (18) $\times 10^{1}$ \\
\hline$\gamma /{ }^{\circ}$ & 90.00 \\
\hline $\mathrm{V} / \AA^{3}$ & $1296.87(13)$ \\
\hline $\mathrm{Z}$ & 4 \\
\hline $\mathrm{D}_{\text {calc }}\left(\mathrm{g} / \mathrm{cm}^{3}\right)$ & 1.364 \\
\hline$\mu\left(\mathrm{mm}^{-1}\right)$ & 0.39 \\
\hline Colour / Shape & Colourless / needles \\
\hline Wavelength & Mo $K a(0.71073 \AA)$. \\
\hline Temperature & $298 \mathrm{~K}$ \\
\hline Theta range for collection $/{ }^{\circ}$ & $2.910-27.485$ \\
\hline Reflections collected & 5158 \\
\hline Independent reflections & 3435 \\
\hline Data / restraints / parameters & $1235 / 0 / 154$ \\
\hline Goodness of fit on $\mathrm{F}^{2}$ & 1.629 \\
\hline Final $R$ indices $[\mathrm{I}>2 \sigma(\mathrm{I})]$ & 0.042 \\
\hline $\mathrm{R}$ indices (all data) & 0.152 \\
\hline Largest difference peak / hole & $0.73 /-0.66$ \\
\hline
\end{tabular}

TABLE 2. Selected bond lengths $(\AA)$ of compound 3f.

\begin{tabular}{|ll|ll|}
\hline $\mathrm{S} 1-\mathrm{C} 7$ & $1.709(2)$ & $\mathrm{N} 5-\mathrm{C} 8$ & $1.299(2)$ \\
$\mathrm{S} 2-\mathrm{C} 8$ & $1.750(2)$ & $\mathrm{N} 6-\mathrm{C} 7$ & $1.355(2)$ \\
$\mathrm{S} 2-\mathrm{C} 9$ & $1.756(2)$ & $\mathrm{C} 9-\mathrm{C} 10$ & $1.388(3)$ \\
$\mathrm{N} 3-\mathrm{C} 8$ & $1.371(2)$ & $\mathrm{C} 9-\mathrm{C} 13$ & $1.378(3)$ \\
$\mathrm{N} 3-\mathrm{C} 10$ & $1.401(3)$ & $\mathrm{C} 10-\mathrm{C} 12$ & $1.392(3)$ \\
$\mathrm{N} 3-\mathrm{C} 14$ & $1.447(3)$ & $\mathrm{C} 11-\mathrm{C} 17$ & $1.489(3)$ \\
$\mathrm{N} 4-\mathrm{C} 7$ & $1.317(3)$ & $\mathrm{C} 12-\mathrm{C} 15$ & $1.381(4)$ \\
$\mathrm{N} 4-\mathrm{C} 11$ & $1.453(3)$ & $\mathrm{C} 13-\mathrm{C} 16$ & $1.381(3)$ \\
$\mathrm{N} 5-\mathrm{N} 6$ & $1.416(2)$ & $\mathrm{C} 15-\mathrm{C} 16$ & $1.370(4)$ \\
\hline
\end{tabular}

TABLE 3. Selected bond angels (degree) of compound $3 \mathrm{f}$.

\begin{tabular}{|c|c|c|c|}
\hline $\mathrm{C} 8-\mathrm{S} 2-\mathrm{C} 9$ & $90.81(11)$ & $\mathrm{C} 12-\mathrm{C} 15-\mathrm{C} 16$ & $121.90(2)$ \\
\hline $\mathrm{C} 8-\mathrm{N} 3-\mathrm{C} 10$ & $114.00(2)$ & $\mathrm{S} 2-\mathrm{C} 8-\mathrm{N} 5$ & $128.10(2)$ \\
\hline $\mathrm{C} 8-\mathrm{N} 3-\mathrm{C} 14$ & $121.90(2)$ & $\mathrm{N} 3-\mathrm{C} 8-\mathrm{N} 5$ & $120.70(2)$ \\
\hline $\mathrm{C} 10-\mathrm{N} 3-\mathrm{C} 14$ & $124.00(2)$ & $\mathrm{S} 2-\mathrm{C} 9-\mathrm{C} 10$ & $111.10(2)$ \\
\hline $\mathrm{C} 7-\mathrm{N} 4-\mathrm{C} 11$ & $125.40(2)$ & $\mathrm{S} 2-\mathrm{C} 9-\mathrm{C} 13$ & $127.90(2)$ \\
\hline $\mathrm{N} 6-\mathrm{N} 5-\mathrm{C} 8$ & $112.00(2)$ & $\mathrm{C} 10-\mathrm{C} 9-\mathrm{C} 13$ & $121.00(2)$ \\
\hline $\mathrm{N} 5-\mathrm{N} 6-\mathrm{C} 7$ & $117.30(2)$ & $\mathrm{N} 3-\mathrm{C} 10-\mathrm{C} 9$ & $112.70(2)$ \\
\hline $\mathrm{S} 1-\mathrm{C} 7-\mathrm{N} 4$ & $124.00(2)$ & $\mathrm{N} 3-\mathrm{C} 10-\mathrm{C} 12$ & $127.00(2)$ \\
\hline $\mathrm{S} 1-\mathrm{C} 7-\mathrm{N} 6$ & $118.70(2)$ & $\mathrm{C} 9-\mathrm{C} 10-\mathrm{C} 12$ & $120.30(2)$ \\
\hline $\mathrm{N} 4-\mathrm{C} 7-\mathrm{N} 6$ & $117.20(2)$ & $\mathrm{N} 4-\mathrm{C} 11-\mathrm{C} 17$ & $112.40(2)$ \\
\hline $\mathrm{S} 2-\mathrm{C} 8-\mathrm{N} 3$ & $111.20(2)$ & $\mathrm{C} 10-\mathrm{C} 12-\mathrm{C} 15$ & $117.70(2)$ \\
\hline $\mathrm{C} 9-\mathrm{C} 13-\mathrm{C} 16$ & $118.60(2)$ & $\mathrm{C} 13-\mathrm{C} 16-\mathrm{C} 15$ & $120.40(2)$ \\
\hline
\end{tabular}


TABLE 4. Selected torsion angels (degree) of compound $3 f$.

\begin{tabular}{|ll|ll|}
\hline $\mathrm{C} 9-\mathrm{S} 2-\mathrm{C} 8-\mathrm{N} 3$ & $4.4(3)$ & $\mathrm{C} 12-\mathrm{C} 10-\mathrm{N} 3-\mathrm{C} 14$ & $-0.1(4)$ \\
$\mathrm{C} 9-\mathrm{S} 2-\mathrm{C} 8-\mathrm{N} 5$ & $-175.0(4)$ & $\mathrm{N} 3-\mathrm{C} 10-\mathrm{C} 12-\mathrm{C} 15$ & $178.4(6)$ \\
$\mathrm{C} 8-\mathrm{S} 2-\mathrm{C} 9-\mathrm{C} 10$ & $-3.2(3)$ & $\mathrm{C} 12-\mathrm{C} 10-\mathrm{C} 9-\mathrm{S} 2$ & $-179.1(5)$ \\
$\mathrm{C} 10-\mathrm{N} 3-\mathrm{C} 8-\mathrm{S} 2$ & $-4.6(3)$ & $\mathrm{C} 12-\mathrm{C} 10-\mathrm{C} 9-\mathrm{C} 13$ & $1.0(4)$ \\
$\mathrm{C} 10-\mathrm{N} 3-\mathrm{C} 8-\mathrm{N} 5$ & $174.8(5)$ & $\mathrm{C} 9-\mathrm{C} 10-\mathrm{C} 12-\mathrm{C} 15$ & $-1.2(4)$ \\
$\mathrm{C} 8-\mathrm{N} 3-\mathrm{C} 10-\mathrm{C} 9$ & $2.2(3)$ & $\mathrm{C} 17-\mathrm{C} 11-\mathrm{N} 4-\mathrm{C} 7$ & $114.1(5)$ \\
$\mathrm{C} 8-\mathrm{N} 3-\mathrm{C} 10-\mathrm{C} 12$ & $-177.5(6)$ & $\mathrm{C} 10-\mathrm{C} 12-\mathrm{C} 15-\mathrm{C} 16$ & $0.7(4)$ \\
$\mathrm{C} 14-\mathrm{N} 3-\mathrm{C} 8-\mathrm{S} 2$ & $177.9(5)$ & $\mathrm{C} 16-\mathrm{C} 13-\mathrm{C} 9-\mathrm{S} 2$ & $180.0(6)$ \\
$\mathrm{C} 14-\mathrm{N} 3-\mathrm{C} 8-\mathrm{N} 5$ & $-2.6(4)$ & $\mathrm{C} 16-\mathrm{C} 13-\mathrm{C} 9-\mathrm{C} 10$ & $-0.1(4)$ \\
$\mathrm{C} 14-\mathrm{N} 3-\mathrm{C} 10-\mathrm{C} 9$ & $179.6(5)$ & $\mathrm{C} 9-\mathrm{C} 13-\mathrm{C} 16-\mathrm{C} 15$ & $-0.5(4)$ \\
$\mathrm{C} 14-\mathrm{N} 3-\mathrm{C} 10-\mathrm{C} 12$ & $-0.1(4)$ & $\mathrm{C} 16-\mathrm{C} 15-\mathrm{C} 12-\mathrm{C} 10$ & $0.7(4)$ \\
$\mathrm{C} 11-\mathrm{N} 4-\mathrm{C} 7-\mathrm{S} 1$ & $1.7(3)$ & $\mathrm{C} 12-\mathrm{C} 15-\mathrm{C} 16-\mathrm{C} 13$ & $0.2(4)$ \\
$\mathrm{C} 11-\mathrm{N} 4-\mathrm{C} 7-\mathrm{N} 6$ & $-177.0(5)$ & $\mathrm{C} 15-\mathrm{C} 16-\mathrm{C} 13-\mathrm{C} 9$ & $-0.5(4)$ \\
$\mathrm{C} 7-\mathrm{N} 4-\mathrm{C} 11-\mathrm{C} 17$ & $114.1(5)$ & $\mathrm{C} 13-\mathrm{C} 16-\mathrm{C} 15-\mathrm{C} 12$ & $0.2(4)$ \\
$\mathrm{N} 6-\mathrm{N} 5-\mathrm{C} 8-\mathrm{S} 2$ & $-2.2(3)$ & $\mathrm{C} 7-\mathrm{N} 6-\mathrm{C} 8-\mathrm{N} 5$ & $-59.4(4)$ \\
$\mathrm{N} 6-\mathrm{N} 5-\mathrm{C} 8-\mathrm{N} 3$ & $178.5(5)$ & $\mathrm{N} 4-\mathrm{C} 7-\mathrm{N} 6-\mathrm{N} 5$ & $-9.7(3)$ \\
$\mathrm{C} 8-\mathrm{N} 5-\mathrm{N} 6-\mathrm{C} 7$ & $140.5(4)$ & $\mathrm{S} 2-\mathrm{C} 8-\mathrm{N} 5-\mathrm{N} 6$ & $-2.2(3)$ \\
$\mathrm{N} 5-\mathrm{N} 6-\mathrm{C} 7-\mathrm{S} 1$ & $171.6(4)$ & $\mathrm{S} 2-\mathrm{C} 9-\mathrm{C} 10-\mathrm{N} 3$ & $1.3(3)$ \\
$\mathrm{N} 5-\mathrm{N} 6-\mathrm{C} 7-\mathrm{N} 4$ & $-9.7(3)$ & $\mathrm{C} 12-\mathrm{C} 10-\mathrm{N} 3-\mathrm{C} 8$ & $-177.5(6)$ \\
$\mathrm{C} 7-\mathrm{N} 6-\mathrm{N} 5-\mathrm{C} 8$ & $140.5(4)$ & $\mathrm{C} 9-\mathrm{C} 10-\mathrm{N} 3-\mathrm{C} 14$ & $179.6(5)$ \\
$\mathrm{C} 9-\mathrm{C} 10-\mathrm{N} 3-\mathrm{C} 8$ & $2.2(3)$ & $\mathrm{N} 3-\mathrm{C} 10-\mathrm{C} 9-\mathrm{C} 13$ & $-178.7(5)$ \\
\hline
\end{tabular}

The C7-S1 bond distance of 1.709 (2) $\AA$ is being intermediate between 1.82 $\AA$ for $\mathrm{C}-\mathrm{S}$ single bond and $1.56 \AA$ for $\mathrm{C}=\mathrm{S}$ double bond ${ }^{(25)}$ (Fig. 2 and Table 2). Moreover, the two C7-N4 and C7-N6 bonds have distance values of 1.317 (3) and 1.355 (2) $\AA$, respectively, which are intermediate between $1.47 \AA$ for $\mathrm{C}-\mathrm{N}$ single bond and $1.28 \AA$ for $\mathrm{C}=\mathrm{N}$ double bond ${ }^{(26)}$. These bond distances are indicative of some double bond character of $\mathrm{C} 7-\mathrm{S} 1, \mathrm{C} 7-\mathrm{N} 4$ and $\mathrm{C} 7-\mathrm{N} 6$ bonds, suggesting an extensive electron delocalization involving the N6C7(S1) - N4 moiety (Fig. 3). Apparently, such delocalization may be enhanced by the almost planarity of these bonds where the torsion angels $\mathrm{C} 11-\mathrm{N} 4-\mathrm{C} 7-$ $\mathrm{S} 1, \mathrm{~N} 5-\mathrm{N} 6-\mathrm{C} 7-\mathrm{S} 1$ and N5-N6-C7-N4 have values of 1.7 (3), 171.6 (4) and $-9.7(3)^{\circ}$ which are very close to 0 and/or $180^{\circ}$. However, the N5-N6 and N5 - C8 bonds have almost retained their single and double bonding characters where they have bond distance values of 1.416 (2) and 1.299 (2) $\AA$ (Table 2), respectively ${ }^{(26)}$. Moreover, the $\mathrm{C}=\mathrm{S}$ and $\mathrm{N}-\mathrm{N}$ bonds exhibited the $E$-configuration where they are trans to each other (Fig. $2 \& 3$ ).

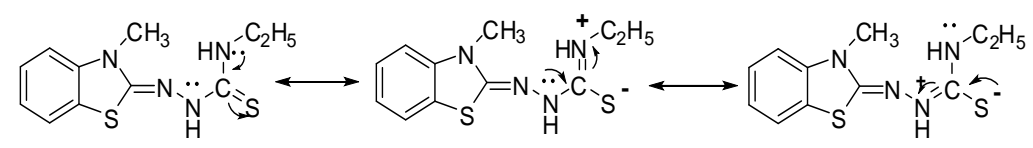

Fig. 3. The electronic resonance of compound $3 \mathrm{f}$.

Egypt. J. Chem. 59, No. 5 (2016) 
Effect of heat and sunlight on the semicarbazone $3 a$

When compound $3 \mathrm{a}$ was heated in a cold finger sublimator at $220{ }^{\circ} \mathrm{C}$ (bath temperature) under reduced pressure for $30 \mathrm{~min}$, two different substances were produced (Scheme 3). The colourless needles that sublimed were identified as $\mathrm{N}$, $\mathrm{N}^{`}$-diethylurea $(4)^{(27,28)}$ by m.p., mixed m.p., comparative IR and MS spectra. Purification of the remained substance gave a yellow crystalline compound which was proved to be 1,3-bis(3-methylbenzo[d]thiazol-2(3H)-ylidene) hydrazine $(5)^{(29)}$ (Scheme 3). An ORTEP overview of compound 5 is represented in Fig. $4^{(29)}$.

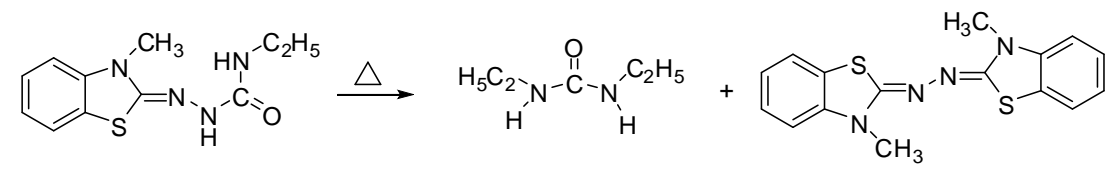

Scheme 3. Thermolysis of compound 3a.

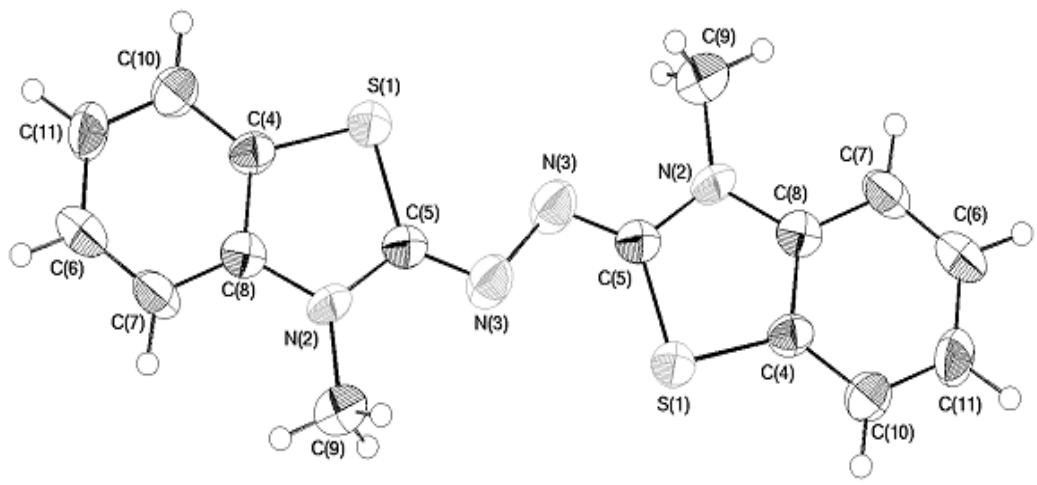

Fig. 4. An ORTEP overview of the azine 5.

Previous works ${ }^{(30-32)}$ reported that, thermolysis of semicarbazones (A) occurs through formation of the reactive $\mathrm{N}$-substituted isocyanate intermediates (B) followed by the unstable N-substituted isocyanate dimmers (C) which can be converted in situ to the corresponding azines (D) (Fig. 5) ${ }^{(30,31)}$ in addition to the $\mathrm{N}$-substituted ureas, carbamates and/or $\beta$-lactams. 


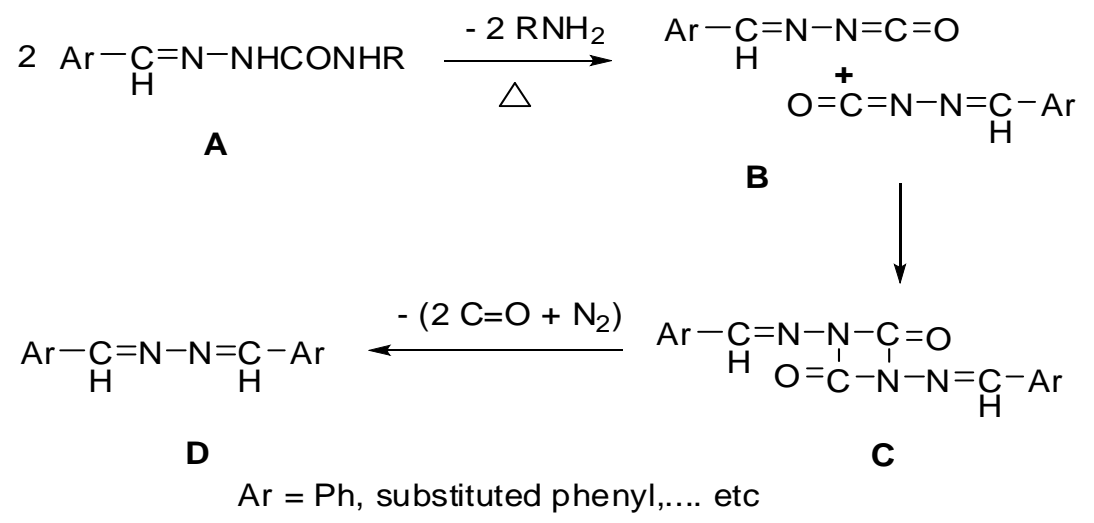

Fig. 5. Thermolysis of semicarbazones.

On the other hand, the semicarbazone 3 a was found to be highly stable against light. Thus, compound 3a was almost quantitatively recovered (92\%) (m.p., mixed m.p., comparative MS and IR spectra) after its exposure to sun light in methanol for 60 days (September - October).

The Antimicrobial evaluation of compounds 1 and $3 a-j$

The newly synthesized semicarbazones and thiosemicarbazones $3 \mathrm{a}-\mathrm{j}$ as well as the starting hydrazone 1 were screened in vitro against two Gram +ve bacteria (as Bacillus subtilis and Staphylococcus aureus), two Gram -ve bacteria (as Escherichia coli and Pseudomonas aeuroginosa) and two fungal species (as Aspergillus flavus and Candida albicans) by using a modified Kirby-Bauer disc diffusion method ${ }^{(33)}$. Ampicillin and Amphotericin B were taken as reference drugs for antimicrobial and antifungal screenings, respectively. The results expressed as the inhibition zone diameter ( $\mathrm{mm} / \mathrm{mg}$ Sample) are compiled in Table 5 and represented in Fig. 6. Among the tested compounds, hydrazone (1) was found to be the most active against the four screened bacterial species. Meanwhile, among the ten synthesized compounds $3 \mathrm{a}-\mathrm{j}$, the thiosemicarbazone $(3 \mathrm{~g})$ exhibited the highest activity followed by compounds $3 \mathrm{j}$ and $3 \mathrm{i}$ which showed a moderate activity. The $\mathrm{MIC}_{90}$ value for compound 1 was determined using agar dilution method where it recorded a value of $9 \mathrm{mg} / \mathrm{ml}$ against Pseudomonas aeuroginosa. Moreover, the tested bacterial species were found to be slightly sensitive for compounds $3 \mathrm{a}, 3 \mathrm{e}$ and $3 \mathrm{~h}$ except for Staphylococcus aureus which is insensitive for the semicarbazone $3 \mathrm{a}$. Compounds $3 \mathrm{~b}, 3 \mathrm{c}, 3 \mathrm{~d}$ and $3 \mathrm{f}$ were found to be inactive against the four screened bacterial strains. On the other hand, the tested compounds were found to be inactive against the two screened fungal species except for compound 1. It showed a high activity only against Aspergillus flavus where it recorded an inhibition zone diameter value of $16(\mathrm{~mm} / \mathrm{mg})$ which is very close to that of the standard drug, amphotericin B (17 $\mathrm{mm} / \mathrm{mg}$ ) (Table 5 and Fig. 6). The moderate and /or negative antimicrobial activity of the synthesized hydrazones $3 \mathrm{a}-\mathrm{j}$ might come from their high electron density caused by the mesomeric effect (Fig. 3) which make the diffusion of

Egypt. J. Chem. 59, No. 5 (2016) 
these compounds more difficult through the body of the bacteria ${ }^{(34,35)}$.

\section{Conclusion}

In the present investigation, we have successfully synthesized a series of novel semicarbazone and thiosemicarbazone derivatives through a simple and direct method by reacting 3-methyl-2-benzothiazolinone hydrazone (1) with some seleceted isocyanate and isothiocyanate reagents. The new synthesizes products $(3 a-j)$ are fully characterized through the spectral $\left({ }^{1} \mathrm{H}\right.$ NMR, $\left.{ }^{13} \mathrm{C} \mathrm{NMR}, \mathrm{IR}, \mathrm{MS}\right)$ and $\mathrm{X}$-ray crystallographic studies. The $-\mathrm{N}-\mathrm{N}-$ bond in $3 \mathrm{a}$ is the most vulnerable site of attack due to thermolysis leading to $\mathrm{N}, \mathrm{N}$-diethylurea (4) in addition to the dimeric product 5. On the other hand, compound $3 \mathrm{a}$ exerted a high stability against the solar $\mathrm{UV}$-irradiation where it was quantitatively recovered after a long exposure period (60 days). Some of the synthesized compounds as well as the starting hydrazone 1 were found to exert antimicrobial activity against B. subtilis $\left(G^{+}\right)$, E. coli $\left(\mathrm{G}^{-}\right), P$. aeruginosa $\left(\mathrm{G}^{-}\right)$and $S$. aureus $\left(\mathrm{G}^{+}\right)$, A. flavus and/or $C$. albicans microbial strains.

TABLE 5. The antimicrobial activity of the hydrazone 1 and the synthesized semicarbazone and thiosemicarbazone derivatives $3 a-j$ expressed in inhibition zone diameter ( $\mathrm{mm} / \mathrm{mg}$ Sample).

\begin{tabular}{|c|c|c|c|c|c|c|}
\hline \multirow[b]{2}{*}{ Sample } & \multicolumn{6}{|c|}{ Inhibition zone diameter (mm / mg Sample) } \\
\hline & 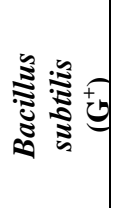 & 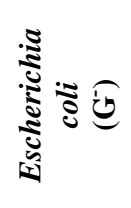 & 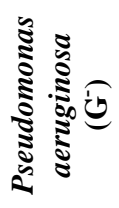 & 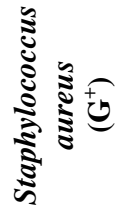 & 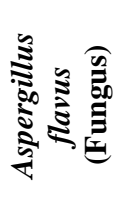 & 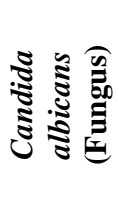 \\
\hline Ampicillin* & 21 & 21 & 22 & 19 & -- & -- \\
\hline $\begin{array}{c}\text { Amphotericin } \\
\text { B** }\end{array}$ & $\begin{array}{l}- \\
--\end{array}$ & -- & -- & -- & 17 & 20 \\
\hline 1 & 17 & 17 & 18 & 16 & 16 & 0.0 \\
\hline $3 \mathrm{a}$ & 9 & 9 & 9 & 0.0 & 0.0 & 0.0 \\
\hline $3 b$ & 0.0 & 0.0 & 0.0 & 0.0 & 0.0 & 0.0 \\
\hline $3 \mathrm{c}$ & 0.0 & 0.0 & 0.0 & 0.0 & 0.0 & 0.0 \\
\hline $3 \mathrm{~d}$ & 0.0 & 0.0 & 0.0 & 0.0 & 0.0 & 0.0 \\
\hline $3 \mathrm{e}$ & 10 & 9 & 9 & 10 & 0.0 & 0.0 \\
\hline $3 \mathrm{f}$ & 0.0 & 0.0 & 0.0 & 0.0 & 0.0 & 0.0 \\
\hline $3 g$ & 15 & 14 & 14 & 13 & 0.0 & 0.0 \\
\hline $3 \mathrm{~h}$ & 9 & 9 & 9 & 9 & 0.0 & 0.0 \\
\hline $3 \mathrm{i}$ & 12 & 11 & 11 & 11 & 0.0 & 0.0 \\
\hline $3 \mathrm{j}$ & 13 & 13 & 14 & 12 & 0.0 & 0.0 \\
\hline
\end{tabular}

Standards: * antibacterial agent $-* *$ antifungal agent 


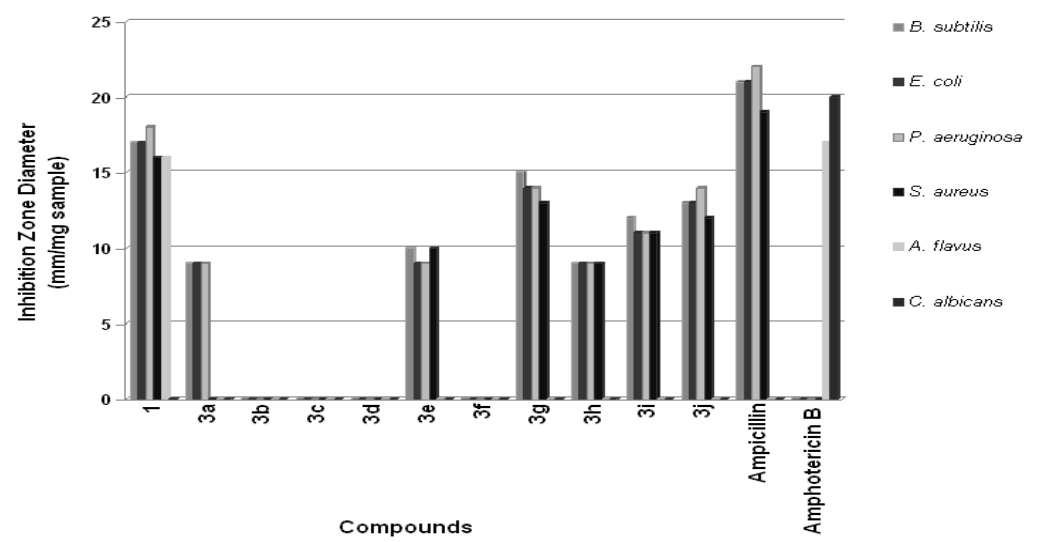

Fig. 6. The antimicrobial evaluation for compound 1 and derivatives 3a-j.

General

\section{Experimental}

The reactions of airsensitive reagents were carried out in flame-dried glassware under an atmosphere of dry argon. Solvents were purified and dried according to usual procedures. 3-Methyl-2-benzothiazolinone hydrazone (1) was prepared according to a known procedure ${ }^{(36)}$. Isocyanates and isothiocyanates are commercially available. The photo experiment was carried out in Schlenk tube of Pyrex glass. The tubes were sealed while a stream of dry nitrogen was passing through. Melting points were recorded on an electrothermal melting point apparatus and were uncorrected. The infrared spectra were obtained from $\mathrm{KBr}$ disks using JASCO FT/IR-300E Fourier Transformation Infrared Spectrophotometer and reported in $\mathrm{cm}^{-1}$. The ${ }^{1} \mathrm{H}$ NMR spectra were recorded on JEOL 500 ECA (running at $500 \mathrm{MHz}$ ) and/or JEOL JNM-EX 270 (running at $270 \mathrm{MHz}$ ). The ${ }^{13} \mathrm{C}$ NMR spectra were recorded on JEOL 500 ECA (running at $125 \mathrm{MHz})$. Chemical shifts $(\delta)$ are reported in ppm downfield from tetramethylsilane (TMS). Mass spectra were recorded on Finnigan SSQ 7000 Spectrometer at $70 \mathrm{eV}$. The elemental analyses were carried out at the Micro Analytical Unit, Cairo University, Egypt. X-ray diffraction: Intensity data collection were performed with Kappa-CCD Enraf Nonius FR 590 Single crystal Diffractometer. The structures were solved by direct methods using the SIR92 program $^{(37)}$ and refined using maXus ${ }^{(38)}$. The molecular graphics were made with ORTEP $^{(39)}$. Crystallographic data (CIF) for the structure reported in this article has been deposited in the Cambridge Crystallographic Data Centre (CCDC) as supplementary publication No.1494262. Copies of the data can be obtained, free of charge, on application to the CCDC, 12 Union Road, Cambridge CB2 1EZ, UK ( FAX: +44 (1223) 336-033; E-mail: deposite@ccdc.cam.ac.uk). The antimicrobial evaluation was carried out at the Micro Analytical Centre, Faculty of Science, Cairo University, Cairo, Egypt.

Egypt. J. Chem. 59, No. 5 (2016) 
Chemistry

Synthesis of 2-(3-methylbenzo[d]thiazol-2(3H)-ylidene)hydrazinecarboxamide derivatives $3 a-j$.

To a stirred solution of hydrazone (1) $(0.005$ mole, $0.9 \mathrm{~g})$ in dry 1,4-dioxane, the appropriate isocyanate and/or isothiocyanate reagent $(2 \mathrm{a}-\mathrm{j})(0.01 \mathrm{~mole})$ was added followed by few drops of triethylamine under dry argon atmosphere. The reaction mixture was stirred for $24 \mathrm{hr}$ at room temperature where the materials that precipitated were collected, washed with cold diethyl ether and recrystallized from the appropriate solvent to give compounds $3 \mathrm{a}-\mathrm{j}$, respectively.

\footnotetext{
N-Ethyl-2-(3-methylbenzo[d]thiazol-2(3H)-ylidene)hydrazinecarboxamide (3a)

Colorless crystals yield: $88 \%$ (1.1 g), m.p. $200{ }^{\circ} \mathrm{C}$ (acetonitrile). IR (KBr,
} $\left.v_{\max }, \mathrm{cm}^{-1}\right): 3369(\mathrm{~N}-\mathrm{H}), 3130(\mathrm{C}-\mathrm{H}$, aromatic $), 2962(\mathrm{C}-\mathrm{H}$, aliphatic $), 1653$ $(\mathrm{C}=\mathrm{O}), 1610\left(\mathrm{C}=\mathrm{N}\right.$, exocyclic), $1585\left(\mathrm{C}=\mathrm{C}\right.$, aromatic). ${ }^{1} \mathrm{H}$ NMR $(500 \mathrm{MHz}$, DMSO- $\left.d_{6}, \delta \mathrm{ppm}\right): 1.02\left(\mathrm{t}, \mathrm{J}_{\mathrm{HH}}=6.9 \mathrm{~Hz}, 3 \mathrm{H}, \mathrm{CH}_{2}-\mathrm{CH}_{3}\right), 3.11\left(\mathrm{q}, \mathrm{J}_{\mathrm{HH}}=6.9 \mathrm{~Hz}\right.$, $2 \mathrm{H}, \mathrm{CH}_{2}-\mathrm{CH}_{3}$ ), 3.46 (s, 3H, N-CH $\left.\boldsymbol{H}_{3}\right), 6.40$ (s, 1H, NH, D $\mathrm{D}_{2}$ exchangeable), 7.01 $\left(\mathrm{t}, \mathrm{J}_{\mathrm{HH}}=7.6 \mathrm{~Hz}, 1 \mathrm{H}\right.$, benzothiazole ring $), 7.15\left(\mathrm{~d}, \mathrm{~J}_{\mathrm{HH}}=7.6 \mathrm{~Hz}, 1 \mathrm{H}\right.$ benzothiazole ring), $7.28\left(\mathrm{t}, \mathrm{J}_{\mathrm{HH}}=7.6 \mathrm{~Hz}, 1 \mathrm{H}\right.$, benzothiazole ring), $7.53\left(\mathrm{~d}, \mathrm{~J}_{\mathrm{HH}}=7.6 \mathrm{~Hz}, 1 \mathrm{H}\right.$ benzothiazole ring), 8.21 ( $\mathrm{s}, \mathrm{NH}, \mathrm{D}_{2} \mathrm{O}$ exchangeable). ${ }^{13} \mathrm{C}$ NMR $(125 \mathrm{MHz}$, DMSO- $d_{6}, \delta$ ppm): $16.29\left(\mathrm{CH}_{2}-\boldsymbol{C H}_{3}\right), 31.00\left(\mathrm{~N}-\boldsymbol{C H}_{3}\right), 34.5\left(\boldsymbol{C} \mathrm{H}_{2}-\mathrm{CH}_{3}\right), 109.78$, $121.52,122.50,122.83,127.06,141.77$ (aromatic carbons), $158.71(\boldsymbol{C}=\mathrm{O})$, $160.96(\boldsymbol{C}=\mathrm{N})$. MS $(\mathrm{EI}, 70 \mathrm{eV}): \mathrm{m} / \mathrm{z}(\%)=250(20)\left[\mathrm{M}^{+}\right]$. Anal. Calcd $(\%)$ for $\mathrm{C}_{11} \mathrm{H}_{14} \mathrm{~N}_{4} \mathrm{OS}$ (250.32): C, 52.78; H, 5.64; N, 22.38; S, 12.81. Found (\%): C, $52.85 ; \mathrm{H}, 5.60 ; \mathrm{N}, 22.32 \mathrm{~S}, 12.78$.

N-tert-Butyl-2-(3-methylbenzo[d]thiazol-2(3H)-ylidene)hydrazinecarboxamide (3b)

Colorless crystals, yield: $86 \%(1.2 \mathrm{~g}), \mathrm{mp} 206{ }^{\circ} \mathrm{C}$ (acetonitrile). IR (KBr, $\left.v_{\max }, \mathrm{cm}^{-1}\right): 3302(\mathrm{~N}-\mathrm{H}), 3095(\mathrm{C}-\mathrm{H}$, aromatic $), 2964(\mathrm{C}-\mathrm{H}$, aliphatic $), 1658$ $(\mathrm{C}=\mathrm{O}), 1613\left(\mathrm{C}=\mathrm{N}\right.$, exocyclic), $1570\left(\mathrm{C}=\mathrm{C}\right.$, aromatic). ${ }^{1} \mathrm{H}$ NMR $(500 \mathrm{MHz}$, DMSO- $d_{6}, \delta$ ppm): $1.29\left(\mathrm{~s}, 9 \mathrm{H}, \mathrm{C}-\left(\mathrm{CH}_{3}\right)_{3}\right), 3.43\left(\mathrm{~s}, 3 \mathrm{H}, \mathrm{N}-\mathrm{CH}_{3}\right), 5.79(\mathrm{~s}, \mathrm{NH}$, $\mathrm{D}_{2} \mathrm{O}$ exchangeable), $7.02\left(\mathrm{t}, \mathrm{J}_{\mathrm{HH}}=6.9 \mathrm{~Hz}, 1 \mathrm{H}\right.$, benzothiazole ring), $7.15\left(\mathrm{~d}, \mathrm{~J}_{\mathrm{HH}}=\right.$ $8.1 \mathrm{~Hz}, 1 \mathrm{H}$, benzothiazole ring), $7.29\left(\mathrm{t}, \mathrm{J}_{\mathrm{HH}}=8.1 \mathrm{~Hz}, 1 \mathrm{H}\right.$, benzothiazole ring), $7.54\left(\mathrm{~d}, \mathrm{~J}_{\mathrm{HH}}=6.9 \mathrm{~Hz}, 1 \mathrm{H}\right.$, benzothiazole ring), $8.09\left(\mathrm{~s}, 1 \mathrm{H}, \mathrm{NH}, \mathrm{D}_{2} \mathrm{O}\right.$ exchangeable). ${ }^{13} \mathrm{C}$ NMR (125 MHz, DMSO- $\left.d_{6}, \delta \mathrm{ppm}\right): 29.59\left(\mathrm{C}\left(\boldsymbol{C H}_{3}\right)_{3}\right), 30.97$ $(\mathrm{N}-\boldsymbol{C H} 3), 49.89\left(\boldsymbol{C}\left(\mathrm{CH}_{3}\right)_{3}\right), 109.83,121.54,122.43,122.83,127.09,141.65$ (aromatic carbons), $157.67(\boldsymbol{C}=\mathrm{O}), 159.92(\boldsymbol{C}=\mathrm{N}) . \mathrm{MS}(70 \mathrm{eV}): \mathrm{m} / \mathrm{z}(\%)=278$ (32) $\left[\mathrm{M}^{+}\right]$. Anal. Calcd (\%) for $\mathrm{C}_{13} \mathrm{H}_{18} \mathrm{~N}_{4} \mathrm{OS}$ (278.37): C, 56.09; H, 6.52; N, 20.13; S, 11.52. Found (\%): C, 56.17; H, 6.50; N, 20.08; S, 11.56.

$N$-(3-Chlorophenyl)-2- (3-methylbenzo[d]thiazol-2 (3H)-ylidene) hydrazinecarboxamide $(3 \mathrm{c})$

Colourless crystals, yield: $72 \%(1.2 \mathrm{~g})$, m.p. $186{ }^{\circ} \mathrm{C}$ (acetonitrile). IR (KBr, $\left.v_{\max }, \mathrm{cm}^{-1}\right): 3303(\mathrm{~N}-\mathrm{H}), 3160(\mathrm{C}-\mathrm{H}$, aromatic $), 1708(\mathrm{C}=\mathrm{O}), 1670(\mathrm{C}=\mathrm{N})$, $1583\left(\mathrm{C}=\mathrm{C}\right.$, aromatic), $765\left(\mathrm{C}-\mathrm{Cl}\right.$, aromatic). ${ }^{1} \mathrm{H}$ NMR $\left(270 \mathrm{MHz}, \mathrm{DMSO}-d_{6}, \delta\right.$ 
ppm): 3.45 (s, 3H, N-CH $H_{3}$ ), 5.45 (s, $\mathrm{NH}, \mathrm{D}_{2} \mathrm{O}$ exchangeable), 6.50 (d, $\mathrm{J}_{\mathrm{HH}}=7.6$ $\mathrm{Hz}, 1 \mathrm{H}$, aromatic $), 7.02\left(\mathrm{t}, \mathrm{J}_{\mathrm{HH}}=7.6 \mathrm{~Hz}, 1 \mathrm{H}\right.$, benzothiazole ring $), 7.07\left(\mathrm{t}, \mathrm{J}_{\mathrm{HH}}=\right.$ $7.6 \mathrm{~Hz}, 1 \mathrm{H}$, aromatic), $7.17\left(\mathrm{~d}, \mathrm{~J}_{\mathrm{HH}}=7.6 \mathrm{~Hz}, 1 \mathrm{H}\right.$, benzothiazole ring), $7.29(\mathrm{t}$, $\mathrm{J}_{\mathrm{HH}}=7.6 \mathrm{~Hz}, 1 \mathrm{H}$, benzothiazole ring), 7. $45\left(\mathrm{~d}, \mathrm{~J}_{\mathrm{HH}}=7.6 \mathrm{~Hz}, 1 \mathrm{H}\right.$, aromatic $), 7.54$ $\left(\mathrm{d}, \mathrm{J}_{\mathrm{HH}}=7.6 \mathrm{~Hz}, 1 \mathrm{H}\right.$, benzothiazole ring), $7.71(\mathrm{~s}, 1 \mathrm{H}$, aromatic $), 7.80(\mathrm{~s}, 1 \mathrm{H}$, $\mathrm{N} H, \mathrm{D}_{2} \mathrm{O}$ exchangeable). MS $(70 \mathrm{eV}): \mathrm{m} / \mathrm{z}(\%)=332(8)\left(\right.$ based on $\left.{ }^{35} \mathrm{Cl}\right)$ and 334 (3) (based on ${ }^{37} \mathrm{Cl}$ ) $\left[\mathrm{M}^{+}\right]$. Anal. Calcd (\%) for $\mathrm{C}_{15} \mathrm{H}_{13} \mathrm{ClN}_{4} \mathrm{OS}$ (332.81): C, 54.13; H, 3.94; Cl, 10.65; N, 16.83; S, 9.63. Found (\%): C, 54.04; H, 3.97; Cl, 10.57; N, $16.78 ;$ S, 9.67 .

N-(3,4- Dichlorophenyl)-2- (3-methylbenzo [d]thiazol-2 (3H) -ylidene) hydrazinecarbox- amide (3d)

Colourless crystals, yield $76 \%$ (1.4 g), m.p. $226-228{ }^{\circ} \mathrm{C}$ (1,4-dioxane). IR $\left(\mathrm{KBr}, v_{\max }, \mathrm{cm}^{-1}\right): 3355,3190(\mathrm{~N}-\mathrm{H}), 3065(\mathrm{C}-\mathrm{H}$, aromatic $), 2920(\mathrm{C}-\mathrm{H}$, aliphatic), $1677(\mathrm{C}=\mathrm{O}), 1626(\mathrm{C}=\mathrm{N}), 1576(\mathrm{C}=\mathrm{C}$, aromatic $), 740(\mathrm{C}-\mathrm{Cl}$, aromatic). ${ }^{1} \mathrm{H}$ NMR $\left(270 \mathrm{MHz}, \mathrm{DMSO}-d_{6}, \delta \mathrm{ppm}\right): 3.45$ (s, $\left.3 \mathrm{H}, \mathrm{N}-\mathrm{CH}_{3}\right), 7.05(\mathrm{t}$, $\mathrm{J}_{\mathrm{HH}}=6.9 \mathrm{~Hz}, 1 \mathrm{H}$, benzothiazole ring $), 7.22\left(\mathrm{~d}, \mathrm{~J}_{\mathrm{HH}}=6.9 \mathrm{~Hz}, 1 \mathrm{H}\right.$, benzothiazole ring), $7.32\left(\mathrm{t}, \mathrm{J}_{\mathrm{HH}}=7.6 \mathrm{~Hz}, 1 \mathrm{H}\right.$, benzothiazole ring), $7.50\left(\mathrm{~d}, \mathrm{~J}_{\mathrm{HH}}=7.6 \mathrm{~Hz}, 1 \mathrm{H}\right.$, benzothiazole ring), 7.58-7.63 (m, $2 \mathrm{H}$, aromatic), $7.98(\mathrm{~s}, 1 \mathrm{H}$, aromatic), $8.70(\mathrm{~s}$, $1 \mathrm{H}, \mathrm{NH}, \mathrm{D}_{2} \mathrm{O}$ exchangeable), $9.05\left(\mathrm{~s}, 1 \mathrm{H}, \mathrm{NH}, \mathrm{D}_{2} \mathrm{O}\right.$ exchangeable). $\mathrm{MS}(70 \mathrm{eV}$, EI): $\mathrm{m} / \mathrm{z}(\%)=366(30)[\mathrm{M}+]$ (based on $\left.2^{35} \mathrm{Cl}\right), 368(20)\left[\mathrm{M}^{+}+2\right]\left(\right.$ based on ${ }^{35} \mathrm{Cl}+$ $\left.{ }^{37} \mathrm{Cl}\right), 370(3)\left[\mathrm{M}^{+}+4\right]$ (based on $2{ }^{37} \mathrm{Cl}$ ). Anal. Calcd (\%) for: $\mathrm{C}_{15} \mathrm{H}_{12} \mathrm{Cl}_{2} \mathrm{~N}_{4} \mathrm{OS}$ (367.25): C, 49.06; H, 3.29; Cl, 19.31; N, 15.26; S, 8.73. Found (\%): C, 49.06; H, $3.29 ; \mathrm{Cl}, 19.31 ; \mathrm{N}, 15.26 ; \mathrm{S}, 8.73$.

2-(3-Methylbenzo[d]thiazol-2 (3H)-ylidene)- $N$ - (4-nitrophenyl) hydrazinecarboxamide (3e)

Yellow crystals, yield: $52 \%\left(0.9\right.$ g), m.p. $272-274{ }^{\circ} \mathrm{C}$ (1,4-dioxane). IR $\left(\mathrm{KBr}, v_{\max }, \mathrm{cm}^{-1}\right): 3367,3337(\mathrm{~N}-\mathrm{H}), 3067(\mathrm{C}-\mathrm{H}$, aromatic $), 1698(\mathrm{C}=\mathrm{O})$, $1632(\mathrm{C}=\mathrm{N}), 1598\left(\mathrm{C}=\mathrm{C}\right.$, aromatic), 1533, $1330\left(\mathrm{NO}_{2}\right) .{ }^{1} \mathrm{H}$ NMR $(270 \mathrm{MHz}$, DMSO- $\left.d_{6}, \delta \mathrm{ppm}\right): 3.42\left(\mathrm{NCH}_{3}\right), 7.09\left(\mathrm{t}, \mathrm{J}_{\mathrm{HH}}=7.6 \mathrm{~Hz}, 1 \mathrm{H}\right.$, benzothiazole ring), $7.17-7.62\left(\mathrm{~m}, 5 \mathrm{H}\right.$, aromatic and benzothiazol ring), $8.07\left(\mathrm{~d}, \mathrm{~J}_{\mathrm{HH}}=7.6 \mathrm{~Hz}, 2 \mathrm{H}\right.$, aromatic), $9.57\left(\mathrm{~s}, 1 \mathrm{H}, \mathrm{NH}, \mathrm{D}_{2} \mathrm{O}\right.$ exchangeable), $10.14\left(\mathrm{~s}, 1 \mathrm{H}, \mathrm{NH}, \mathrm{D}_{2} \mathrm{O}\right.$ exchangeable). MS $(70 \mathrm{eV}): \mathrm{m} / \mathrm{z}(\%)=343$ (10). Anal. Calcd (\%) for: $\mathrm{C}_{15} \mathrm{H}_{13} \mathrm{~N}_{5} \mathrm{O}_{3} \mathrm{~S}$ (343.36): C, 52.47; H, 3.82; N, 20.40; S, 9.34. Found (\%): C, $52.40 ; \mathrm{H}, 3.85 ; \mathrm{N}, 20.36 ; \mathrm{S}, 9.30$.

\footnotetext{
N-Ethyl-2-(3-methylbenzo[d]thiazol-2(3H)-ylidene)hydrazinecarbothioamide (3f)

Colourless needles yield: $69 \%(0.9 \mathrm{~g}), \mathrm{mp} 195{ }^{\circ} \mathrm{C}$ (acetonitrile). IR ( $\mathrm{KBr}$, $\left.v_{\max }, \mathrm{cm}^{-1}\right): 3288(\mathrm{~N}-\mathrm{H}), 3093(\mathrm{C}-\mathrm{H}$, aromatic $), 2927(\mathrm{C}-\mathrm{H}$, aliphatic $), 1599$ $(\mathrm{C}=\mathrm{N}), 1535\left(\mathrm{C}=\mathrm{C}\right.$, aromatic), $1160(\mathrm{C}=\mathrm{S}) .{ }^{1} \mathrm{H}$ NMR $\left(500 \mathrm{MHz}, \mathrm{DMSO}-d_{6}, \delta\right.$ ppm): $1.10\left(\mathrm{t}, \mathrm{J}_{\mathrm{HH}}=9.0 \mathrm{~Hz}, 3 \mathrm{H}, \mathrm{CH}_{2} \mathrm{CH}_{3}\right), 3.45\left(\mathrm{~s}, 3 \mathrm{H}, \mathrm{N}-\mathrm{CH}_{3}\right), 3.52$ (q, J $\left.=9.0 \mathrm{~Hz}, 2 \mathrm{H}, \mathrm{CH}_{2}-\mathrm{CH}_{3}\right), 7.09\left(\mathrm{t}, \mathrm{J}_{\mathrm{HH}}=6.9 \mathrm{~Hz}, 1 \mathrm{H}\right.$, benzothiazole ring $), 7.20(\mathrm{~d}$, $\mathrm{J}_{\mathrm{HH}}=6.9 \mathrm{~Hz}, 1 \mathrm{H}$, benzothiazole ring $), 7.35\left(\mathrm{t}, \mathrm{J}_{\mathrm{HH}}=6.9 \mathrm{~Hz}, 1 \mathrm{H}\right.$, benzothiazole Egypt. J. Chem. 59, No. 5 (2016)
} 
ring), $7.58\left(\mathrm{~d}, \mathrm{~J}_{\mathrm{HH}}=6.9 \mathrm{~Hz}, 1 \mathrm{H}\right.$, benzothiazole ring $), 7.75\left(\mathrm{~s}, 1 \mathrm{H}, \mathrm{NH}, \mathrm{D}_{2} \mathrm{O}\right.$ exchangeable), $9.80\left(\mathrm{~s}, 1 \mathrm{H}, \mathrm{NH}, \mathrm{D}_{2} \mathrm{O}\right.$ exchangeable). ${ }^{13} \mathrm{C}$ NMR $(125 \mathrm{MHz}$, DMSO- $\left.d_{6}\right): 15.33\left(\mathrm{CH}_{2} \mathrm{CH}_{3}\right), 31.21\left(\mathrm{~N}-\mathrm{CH}_{3}\right), 38.78\left(\mathrm{CH}_{2} \mathrm{CH}_{3}\right), 110.21,121.97$, 122.37, 122.91, 127.22, 141.41 (aromatic carbons), $162.18(C=\mathrm{N}), 178.41(C=\mathrm{S})$. MS (70eV): $\mathrm{m} / \mathrm{z}(\%)=266(83)\left[\mathrm{M}^{+}\right]$. Anal. Calcd $(\%)$ for $\mathrm{C}_{11} \mathrm{H}_{14} \mathrm{~N}_{4} \mathrm{~S}_{2}(266.39)$ : C, 49.60; H, 5.30; N, 21.03; S, 24.07. Found (\%): C, 49.68; H, 5.27; N, 20.97; S, 24.11.

2-(3-Methylbenzo[d] thiazol-2(3H)-ylidene)- $N$-phenylhydrazinecarbothioamide (3g)

Pale green crystals, yield: $86 \%(1.4 \mathrm{~g}), \mathrm{mp} 176^{\circ} \mathrm{C}$ (acetonitrile). IR $(\mathrm{KBr}$ $\left.v_{\max }, \mathrm{cm}^{-1}\right): 3315(\mathrm{~N}-\mathrm{H}), 3097(\mathrm{C}-\mathrm{H}$, aromatic $), 2920(\mathrm{C}-\mathrm{H}$, aliphatic $), 1620$ $\left(\mathrm{C}=\mathrm{N}\right.$, exocyclic), $1580\left(\mathrm{C}=\mathrm{C}\right.$, aromatic), $1200(\mathrm{C}=\mathrm{S}) .{ }^{1} \mathrm{H}$ NMR $(270 \mathrm{MHz}$, DMSO- $\left.d_{6}, \delta \mathrm{ppm}\right): 3.55\left(\mathrm{~s}, 3 \mathrm{H}, \mathrm{N}-\mathrm{CH}_{3}\right), 7.05-7.65(\mathrm{~m}, 9 \mathrm{H}$, aromatic and benzothiazole ring), $9.30\left(\mathrm{~s}, 1 \mathrm{H}, \mathrm{NH}, \mathrm{D}_{2} \mathrm{O}\right.$ exchangeable), $10.37\left(\mathrm{~s}, 1 \mathrm{H}, \mathrm{NH}, \mathrm{D}_{2} \mathrm{O}\right.$ exchangeable). Anal. Calcd (\%) for $\mathrm{C}_{15} \mathrm{H}_{14} \mathrm{~N}_{4} \mathrm{~S}_{2}$ (314.43): C, 57.30; H, 4.49; N, 17.82; S, 20.40. Found (\%): C, 57.37; H, 4.46; N, 17.78; S, 20.44.

$\mathrm{N}$-(Benzoyl)-2- (3-methylbenzo [d]thiazol-2(3H)
carbothioamide $(3 h)$
Yellow crystals, yield: $55 \%(0.93 \mathrm{~g})$, m. p. 164 (acetonitrile). IR (KBr, $v_{\max }$, $\left.\mathrm{cm}^{-1}\right): 3410,3247(\mathrm{~N}-\mathrm{H}), 3060(\mathrm{C}-\mathrm{H}$, aromatic), $2925(\mathrm{C}-\mathrm{H}$, aliphatic), 1660 $(\mathrm{C}=\mathrm{O}), 1605(\mathrm{C}=\mathrm{N}), 1580\left(\mathrm{C}=\mathrm{C}\right.$, aromatic), $1190(\mathrm{C}=\mathrm{S}) .{ }^{1} \mathrm{H}$ NMR $(270 \mathrm{MHz}$, DMSO- $\left.d_{6}, \delta \mathrm{ppm}\right): 3.57\left(\mathrm{NCH}_{3}\right), 7.10\left(\mathrm{t}, \mathrm{J}_{\mathrm{HH}}=6.9 \mathrm{~Hz}, 1 \mathrm{H}\right.$, benzothiazole ring), $7.30\left(\mathrm{~d}, \mathrm{~J}_{\mathrm{HH}}=6.9 \mathrm{~Hz}, 1 \mathrm{H}\right.$, benzothiazole ring $), 7.38\left(\mathrm{t}, \mathrm{J}_{\mathrm{HH}}=7.6 \mathrm{~Hz}, 1 \mathrm{H}\right.$, benzothiazole ring), $7.50\left(\mathrm{t}, \mathrm{J}_{\mathrm{HH}}=6.9 \mathrm{~Hz}, 2 \mathrm{H}\right.$, aromatic), $7.63-7.70(\mathrm{~m}, 2 \mathrm{H}$, aromatic and benzothiazole ring), $8.00\left(\mathrm{~d}, \mathrm{~J}_{\mathrm{HH}}=7.6 \mathrm{~Hz}, 2 \mathrm{H}\right.$, aromatic), 11.50 (s, $1 \mathrm{H}, \mathrm{NH}, \mathrm{D}_{2} \mathrm{O}$ exchangeable), $13.00\left(\mathrm{~s}, 1 \mathrm{H}, \mathrm{N} H, \mathrm{D}_{2} \mathrm{O}\right.$ exchangeable). $\mathrm{MS}(70 \mathrm{eV}$, $\mathrm{EI}): \mathrm{m} / \mathrm{z}(\%)=342$ (10) Anal. Calcd (\%) for $\mathrm{C}_{16} \mathrm{H}_{14} \mathrm{~N}_{4} \mathrm{OS}_{2}$ (342.44): $\mathrm{C}, 56.12 ; \mathrm{H}$, 4.12; N, 16.36; S, 18.73. Found (\%): C, 56.19; H, 4.10; N, 16.31; S, 18.76.

$N$-(4-Methoxyphenyl)-2-(3-methylbenzo[d]thiazol -2(3H)-ylidene) hydrazinecarbothio- amide (3i)

Colourless leaflets, yield: $81 \%$ (1.4 g), m.p. 174 (acetonitrile). IR (KBr, $v_{\max }$, $\left.\mathrm{cm}^{-1}\right): 3258(\mathrm{~N}-\mathrm{H}), 3099(\mathrm{C}-\mathrm{H}$, aliphatic), $2928(\mathrm{C}-\mathrm{H}$, aliphatic $), 1602$ $(\mathrm{C}=\mathrm{N}), 1577\left(\mathrm{C}=\mathrm{C}\right.$, aromatic), $1196(\mathrm{C}=\mathrm{S}) .{ }^{1} \mathrm{H}$ NMR $\left(500 \mathrm{MHz}\right.$, DMSO- $d_{6}, \delta$ ppm): $3.54\left(\mathrm{~s}, 1 \mathrm{H}, \mathrm{N}-\mathrm{CH}_{3}\right), 3.74\left(\mathrm{~s}, 1 \mathrm{H}, \mathrm{OCH}_{3}\right), 6.89\left(\mathrm{~d}, \mathrm{~J}_{\mathrm{HH}}=8.1 \mathrm{~Hz}, 2 \mathrm{H}\right.$, aromatic, AA`BB` system), 7.09 (t, $\mathrm{J}_{\mathrm{HH}}=7.6 \mathrm{~Hz}, 1 \mathrm{H}$, benzothiazole ring), 7.24 $\left(\mathrm{d}, \quad \mathrm{J}_{\mathrm{HH}}=7.6 \mathrm{~Hz}, 1 \mathrm{H}, \quad\right.$ benzothiazole ring $), 7.35\left(\mathrm{t}, \mathrm{J}_{\mathrm{HH}}=7.6 \mathrm{~Hz}, 1 \mathrm{H}\right.$, benzothiazole ring), $7.40\left(\mathrm{~d}, \mathrm{~J}_{\mathrm{HH}}=8.1 \mathrm{~Hz}, 2 \mathrm{H}\right.$, aromatic, $\mathrm{AA}^{`} \mathrm{BB}^{`}{ }^{`}$ system $), 7.61$ $\left(\mathrm{d}, \mathrm{J}_{\mathrm{HH}}=7.6 \mathrm{~Hz}, 1 \mathrm{H}\right.$, benzothiazole ring $), 9.20\left(\mathrm{~s}, 1 \mathrm{H}, \mathrm{NH}, \mathrm{D}_{2} \mathrm{O}\right.$ exchangeable $)$, 10.2 (s, $1 \mathrm{H}, \mathrm{N} H, \mathrm{D}_{2} \mathrm{O}$ exchangeable). ${ }^{13} \mathrm{C}$ NMR $\left(125 \mathrm{MHz}, \mathrm{DMSO}-d_{6}, \delta \mathrm{ppm}\right)$ : $31.32\left(\mathrm{~N}^{-} \mathrm{CH}_{3}\right), 55.76\left(\mathrm{OCH}_{3}\right), 110.36,113.68,122.09,122.38,122.97,127.31$, 127.46, 132.86, 141.44, 157.12 (aromatic carbons), $162.73(C=\mathrm{N}), 177.45(C=\mathrm{S})$. MS (70eV, EI): $\mathrm{m} / \mathrm{z}(\%)=344$ (10). Anal. Calcd (\%) for $\mathrm{C}_{16} \mathrm{H}_{16} \mathrm{~N}_{4} \mathrm{OS}_{2}$ (344.45): 
C, 55.79; H, 4.68; N, 16.27; S, 18.62. Found (\%): C, 55.86; H, 4.64; N, 16.23; O, S, 18.60 .

2-(3-Methylbenzo [d]thiazol-2 (3H)-ylidene)-N-o- tolylhydrazinecarbothioamide (3j)

Pale yellow crystals, yield $73 \%(1.2 \mathrm{~g})$, m. p. $170{ }^{\circ} \mathrm{C}$ (chloroform/petroleum ether b. r. $\left.80-100{ }^{\circ} \mathrm{C}\right)$. IR $\left(\mathrm{KBr}, v_{\max }, \mathrm{cm}^{-1}\right): 3270(\mathrm{~N}-\mathrm{H}), 3074(\mathrm{C}-\mathrm{H}$, aromatic), $2900(\mathrm{C}-\mathrm{H}$, aliphatic), $1620(\mathrm{C}=\mathrm{N}), 1580(\mathrm{C}=\mathrm{C}$, aromatic $), 1180$ $(\mathrm{C}=\mathrm{S}) .{ }^{1} \mathrm{H}$ NMR $\left(500 \mathrm{MHz}, \mathrm{DMSO}-d_{6}, \delta \mathrm{ppm}\right): 7.07-7.35(\mathrm{~m}, 7 \mathrm{H}$, aromatic and benzothiazole ring), $7.62\left(\mathrm{~d}, \mathrm{~J}_{\mathrm{HH}}=6.9 \mathrm{~Hz}, 1 \mathrm{H}\right.$, benzothiazole ring), $9.12(\mathrm{~s}$, $1 \mathrm{H}, \mathrm{NH}, \mathrm{D}_{2} \mathrm{O}$ exchangeable), 10.24 (s, 1H, NH, $\mathrm{D}_{2} \mathrm{O}$ exchangeable). ${ }^{13} \mathrm{C}$ NMR (125 MHz, DMSO- $d_{6}, \delta$ ppm): $18.41\left(\mathrm{CH}_{3}\right), 31.27\left(\mathrm{~N}_{-} \mathrm{CH}_{3}\right), 110.37,122.10$, $122.39,123.01,126.27,126.76,127.31,128.78,130.49,135.45,138.41,141.47$ (aromatic carbons), $163.04(C=\mathrm{N}), 177.87(C=\mathrm{S}) . \mathrm{MS}(70 \mathrm{eV}, \mathrm{EI}): \mathrm{m} / \mathrm{z}(\%)=328$ (8). Anal Calcd (\%) for $\mathrm{C}_{16} \mathrm{H}_{16} \mathrm{~N}_{4} \mathrm{~S}_{2}$ (328.46): C, 58.51; H, 4.91; N, 17.06; S, 19.52. Found (\%): C, 58.43; H, 4.96; N, 16.99; S, 19.55 .

Thermolysis of compound $3 a$

The semicarbazone $3 \mathrm{a}(0.002$ mole, $0.5 \mathrm{~g})$ was heated in a cold finger sublimator at $220^{\circ} \mathrm{C}$ (bath temperature) under reduced pressure $(0.5 \mathrm{~mm} / \mathrm{Hg})$ for $30 \mathrm{~min}$. The substance that sublimed as well as the residue in the sublimator were collected and recrystallized from the appropriate solvent to give compounds 4 and $\mathbf{5}$, respectively.

\section{$N, N^{`}$-Diethylurea (4)}

Colourless needles, yield $73 \%\left(0.085\right.$ g), m. p. $111{ }^{\circ} \mathrm{C}$ (ethanol) [Ref. ${ }^{(27)}$ : 112-113 $\left.{ }^{\circ} \mathrm{C}\right]$. IR $\left(\mathrm{KBr}, v_{\max }, \mathrm{cm}^{-1}\right): 3310(\mathrm{~N}-\mathrm{H}), 2920(\mathrm{C}-\mathrm{H}$, aliphatic), 1635 $(\mathrm{C}=\mathrm{O}) . \mathrm{MS}(70 \mathrm{eV}, \mathrm{EI}): \mathrm{m} / \mathrm{z}(\%)=116(100)\left[\mathrm{M}^{+}\right]$.

\section{1,3-Bis(3-methylbenzo[d]thiazol-2(3H)-ylidene)hydrazine (5)}

Yellow crystals, yield $67 \%\left(0.22\right.$ g), m.p. $263{ }^{\circ} \mathrm{C}$ (toluene) [Ref. ${ }^{(29)}: 266{ }^{\circ} \mathrm{C}$ ]. IR $\left(\mathrm{KBr}, v_{\max }, \mathrm{cm}^{-1}\right): 3050(\mathrm{C}-\mathrm{H}$, aromatic), 2915(C-H, aliphatic), 1610 $(\mathrm{C}=\mathrm{N}), 1570(\mathrm{C}=\mathrm{C}$, aromatic $)$. MS $(70 \mathrm{eV}, \mathrm{EI}): \mathrm{m} / \mathrm{z}(\%)=326(100)\left[\mathrm{M}^{+}\right]$.

Photochemical action of sunlight on compound $3 a$

A solution of $3 \mathrm{a}(0.01$ mole, $2.5 \mathrm{~g})$ in dry methanol $(200 \mathrm{~mL})$ was exposed to sunlight for 60 days (September-October). The volatile materials were removed under reduced pressure where the semicarbazone $3 \mathrm{a}$ was almost quantitavely recovered $(2.3 \mathrm{~g}, 92 \%)$ after crystallizing the residue from acetonitrile (m.p., mixed m. p., comparative TLC and comparative IR).

\section{The Biological evaluation}

The antimicrobial sensitivity test

Antimicrobial activity of the tested samples was determined using a modified Kirby - Bauer disc diffusion method ${ }^{(33)}$. Briefly, $100 \mu \mathrm{L}$ of the test bacteria/fungi were grown in $10 \mathrm{ml}$ of fresh media until they reached a count of approximately

Egypt. J. Chem. 59, No. 5 (2016) 
108 cells $/ \mathrm{mL}$ for bacteria or 105 cells $/ \mathrm{mL}$ for fungi ${ }^{(40)} .100 \mu \mathrm{L}$ of microbial suspension was spread onto agar (Müller-Hinton agar) plates corresponding to the broth in which they were maintained. Isolated colonies of each organism that might be playing a pathogenic role should be selected from primary agar plates and tested for susceptibility. Plates inoculated with filamentous fungi as Aspergillus flavus at $25^{\circ} \mathrm{C}$ for $48 \mathrm{hr}$; Gram (+) bacteria as Staphylococcus aureus, Bacillus subtilis; Gram (-) bacteria as Escherichia coli, Pseudomonas aeuroginosa they were incubated at $35-37{ }^{\circ} \mathrm{C}$ for $24-48$ hours and yeast as Candida albicans incubated at $30^{\circ} \mathrm{C}$ for $24-48 \mathrm{hr}$. Standard discs of Ampicillin (Antibacterial agent), Amphotericin B (Antifungal agent) served as positive controls for antimicrobial activity but filter discs impregnated with $10 \mu \mathrm{L}$ of solvent (DMSO) were used as a negative control. Blank paper disk with a diameter of $8.0 \mathrm{~mm}$ were impregnated with $10 \mu \mathrm{L}$ of the tested chemical and placed on agar where the chemical diffuses from the disc into the agar. When an organism is placed on the agar it will not grow in the area around the disc if it is susceptible to the tested chemical. The area of no growth around the disc is known as the "Zone of inhibition" whose diameter was measured in millimeters with a sterilized slipping calipers.

Determination of minimum inhibitory concentration $\left(M C_{90}\right)$ for compound 1 against $P$. aeruginosa:

The minimum concentration of a compound which inhibits $90 \%$ of the tested microorganism growth when compared to control (no treatment) is known as $\mathrm{MIC}_{90}$. It is determined by using Agar Dilution Method ${ }^{(41,42)}$. Briefly, stationary - phase cultures of bacteria were prepared at $37^{\circ} \mathrm{C}$ and they were used to inoculate a fresh $5.0 \mathrm{ml}$ culture to an $\mathrm{OD}_{600}$ value (optical density of the sample measured at wave length of $600 \mathrm{~nm}$ ) of 0.05 . The $5.0 \mathrm{ml}$ cultures were then incubated at $37^{\circ} \mathrm{C}$ until an $\mathrm{OD}_{600}$ of 0.10 was achieved from which standardized bacterial suspensions were prepared to a final cell density of $6 \times 10^{5} \mathrm{CFU}$ (the colony forming units) $/ \mathrm{ml}$. Serial dilutions from the treatments $(0-320 \mathrm{mg} / \mathrm{ml})$ were prepared and mixed with $5.0 \mathrm{ml}$ of the standardized bacteria suspension then added to the plates and incubated for $24 \mathrm{hr}$ at $37^{\circ} \mathrm{C}$. The colony forming units (CFU) were counted for each dilution.

\section{References}

1. Cohen, M. L., Epidemiology of drug resistance: Implication for a post-antimicrobial era. Science , 257, 1050-1055 (1992).

2. Cunha, B. A., Antibiotic resistance. Drugs Today 34, 691-698 (1998).

3. Singhal, M. and Paul, A. Antibacterial evaluation of synthesized methyl semicarbazone derivatives. Int. J. Pharm. Sci. Res. 2, 2062-2064 (2011).

4. Gupta, M. K., Sachan, A. K., Pandeya, S. N. and Gangwar, V. S. Synthesis and antibacterial activity of semicarbazones and thiosemicarbazones. Asian J. Chem. 19, 5-9 (2007). 
5. Ahsan, M. J., Amir, M., Bakht, M. A., Hassan, M. Z. and Nomani, M. S., Synthesis and antimicrobial activity of N1-(3-chloro-4-fluorophenyl)-N4-substituted semicarbazones derivatives. Arab. J. Chem. 30, 1-6 (2011).

6. Ibrahim, M. N. and Al-Difar, H.A. Synthesis and antibacterial activity of semicarbazone derivatives of some carbonyl compounds. Der Chemica Sinica 2, 171 $173(2011)$

7. Tehrani, M. H. H., Zarghi, A. and Fathali, S., A modified method for the synthesis of nitrofurazone. Iran. J. Pharm. Res. 2, 67-69 (2003).

8. Pandeya, S. N., Semicarbazone - a versatile therapeutic pharmacophore.for fragment based anticonvulsant drug design. Acta Pharm. 62, 263-286 (2012).

9. Puthucode, R. N., Pugazhenthi, U., Quail, J. W.; Stables, J. P. and Dimmock, J. R., Anticonvulsant activity of various aryl, arylidene and aryloxyaryl semicarbazones. Eur. J. Med. Chem. 33, 595-607 (1998).

10. Pandeya, S. N., Yogeeswari, P. and Stables, J. P., Synthesis and anticonvulsant activity of 4-bromophenyl substituted aryl semicarbazones Eur. J. Med. Chem. 35, $879-886$ (2000).

11. Sriram, D. P., Yogeeswari, P. and Thirumurugan, R. Antituberculous activity of some aryl semicarbazone derivatives. Bioorg. Med. Chem. Lett. 14, 3923-3924 (2004).

12. Dutta, S., Padhye, S., Priyadarsini, K.I. and Newton C. Antioxidant and antiproliferative activity of curcumin semicarbazone. Bioorg. Med. Chem. Lett. 15, 2738-2744 (2005).

13. Ali, S. M. M., Azad, M A. K., Jesmin, M., Ahsan, S., Rahman, M. M., Khanam, J. A., Islam, M. N. and Shahriar, S. M. S., In vivo anticancer activity of vanillin semicarbazone. Asian Pac. J. Trop. Biomed. 438-442 (2012).

14. Singh, H. P., Chauhan, C. S., Pandeya, S. N., Sharma, C. S., Srivastava, B. and Singhal, M., Design, Synthesis, Analgesic and Anti-Inflammatory Activity of Some novel Chalcone semicarbazone derivatives. Der Pharmacia Lettre 2, 460-462 (2010).

15. Mahran, M. A., El-Nassry, S. M. F., Allam, S. R. and El-Zawawy, L. A. Synthesis of some new benzothiazole derivatives as potential antimicrobial and antiparasitic agent. Pharmazie 58, 527 - 530 (2003).

16. Mistry, K. and Desai, K. R., Microwave assisted rapid and efficient synthesis of nitrogen and sulphur containing heterocyclic compounds and their pharmacological evaluation. Indian J. Chem. 45B, 1762 - 1766 (2006).

17. Chaitanya1, M. S., Nagendrappa, G. and Vaidya V. P. Synthesis, biological and pharmacological activities of 2-methyl-4Hpyrimido[2,1-b][1,3] benzo- thiazoles. $J$. Chem. Pharm. Res. 2 (3), 206-213 (2010).

18. Racane, L., Tralic, K. V., Fiser, J. L., Boykin, D. W. and Karminski, Z. G. Synthesis of bis-substituted amidinobenzothiazoles as potential anti-HIV agents. Heterocycles 55, 2085 -2098 (2001).

Egypt. J. Chem. 59, No. 5 (2016) 
19. Stanton, H. L. K., Gambari, R., Chung, H. C., Johny, C. O. T., Filly, C., Albert, S. C. C. Synthesis and anti-cancer activity of benzothiazole containing phthalimide on human carcinoma cell lines. Bioorg. Med. Chem. 16, 3626-3631 (2008).

20. Yoshida, M., Hayakawa, I., Hyashi, N., Agatsuma, T., Oda, Y., Tanzawa, F., Iwasaki, S., Koyama, K., Furukawa, H., Kurakata, S. and Sugano, Y. , Synthesis and biological evaluation of benzothiazole derivatives as potent antitumor agents. Bioorg. Med. Chem. Lett. 15, 3328-3332 (2005).

21. Sreenivasa, M., Jaychand E., Shivakumar, B., Jayrajkumar, K. and Vijaykumar, J., Synthesis of bioactive molecule flurobenzothiazole comprising potent heterocylic moieties for anthelmintic activity. Arch. Pharm. Sci. Res. 1(2), 150-157 (2009).

22. Sadhasivam, G. and Kulanthai, K. Synthesis, characterization, and evaluation of anti-inflammatory and anti-diabetic activity of new benzothiazole derivatives. $J$. Chem. Pharm. Res. 7 (8), $425-431$ (2015).

23. Pattan, S. R., Suresh, C., Pujar, V. D., Reddy, V. V. K., Rasal, V. P. and Kotti, B.C. Synthesis and antidiabetic activity of 2-amino [5(4-sulphonylbenzylidine)-2,4thiazolidinedione]-7-chloro-6-fluorobenzothi- azole. Indian J. Chem. 4B, $2404-$ 2408 (2005).

24. Silverstein, R. M., Webster, G. C. and Kiemle, D. J., Spectrometric Identification of Organic Compounds. ${ }^{7}$ th ed, John Wiley\& Sons Inc: New York, (2005).

25. Wu, D.H., He,C., Duan, C.Y. and You, X.Z., Terephthalaldehydebis (thiosemicarbazone) bis(dimethylformamide) solvate. Acta. Cryst. C56, 1336- 1337 (2000).

26. Allen, F. H., Kennard, O., Watson, D. G., Brammer L., Orpen, A. G. and Taylor, R., Tables of Bond Lengths determined by X-Ray and Neutron Diffraction. Part I .Bond Lengths in Organic Compounds. J. Chem. Soc. Perkin Trans. II, 2 (12), S1-S19 (1987).

27. Papesch, V. and Schröder, E. F., Synthesis of 1-Mono- and 1,3-disubstituted 6aminouracils. Diuretic activity. J. Org. Chem. 16 (12), 1879-1890 (1951).

28. Jagtap, S.R., Pati Jagtap, S.R., Y.P., Panda, A.G. and Bhanage, B.M., Synthesis of 1,3-disubstituted symmetrical/unsymmetrical ureas via $\mathrm{Cs}_{2} \mathrm{CO}_{3}$-catalyzed transamination of ethylene carbonate and primary amines. Synth. Commun. 39 (12), 2093-2100 (2009).

29. Yosef, H.A.A., Preparation, Thermolysis and Photolysis of some new Thiophosphoramidates derived from 3-methyl-2-benzothiazolinone hydrazone Phosphorus, Sulfur, Silicon Relat. Elem. 185, 890-897 (2010).

30. Shah, S. N. and Chudgar, N. K. Thermolysis of semicarbazones to the corresponding azines through reactive $\mathrm{N}$-substituted isocyanate intermediates. Molecules 5, 657-654 (2000).

31. Chudgar, N. K., Shah, S. N. and Vora, R. A., Mesogenic properties as an analytical tool for the pyrolyitic transformation of substituted aryl aldehyde semicarbaz- one to the corresponding benzalazine. Mol. Cryst. Liq. Cryst. 209, $237-$ 241 (1991). 
32. Hofmann, H. and Dlehr, H. P. Reactions of N-carbonylsulfamyl chloride with dienes. Tetrahedron Lett. 1875 (1963).

33. Bauer, A. W., Kirby, W. M. M., Sherris, J. C. and Turck, M. Antibiotic susceptibility testing by a standardized single disk method. Amer. J. Clinic. Path 45 (4), 493-496 (1966).

34. Hania, M. M., Synthesis and antibacterial activity of new oximes, semicarbazones and phenyl hydrazones. Asian J. Chem. 18 (3), 1701-1704 (2006).

35. Hania, M. M., Electron density and biological investigations on metal complexes with an ONO functionalized ligand. Res. J. Pharm. Biolo. Chem. Sci. 2 (4), 12 - 17 (2011).

36. Baker, K. and Fierz-David, H. E., Zur kenntinis der Derivate Benzothiazole. Helv. Chim. Acta. 33, 2011- 2018 (1950).

37. Altomare, A., Cascarano, G., Giacovazzo, C., Guagliardi, A., Burla, M. C., Polidori, G. and Camall, M., SIRPOW.92 - a program for automatic solution of crystal structures by direct methods optimized for powder data. J. Appl. Cryst. 27, 435-436 (1994).

38. Macky, S., Gilmore, C. J., Edwards, C., Stewart, N. and Shankland, K., MaXus Computer Program for the Solution and Refinement of Crystal Structures, Brucker Nonius, The Netherlands; MacScience, Japan and The University of Glasgow, Glasgow, UK, 1999.

39. Johnoson, C. K., ORTEP-II, A. Fortran Thermal-Ellipsoid Program, Report ORNL5138. Oak Ridge National Laboratory, Oak Ridge, Tennessee, USA, 1976.

40. Pfaller, M. A., Burmeister, L., Bartlett, M. A. and Rinaldi. M. G., Multicenter evaluation of four methods of yeast inoculum preparation. J. Clin. Microbiol. 26, 1437-1441 (1988).

41. National Committee for Clinical Laboratory Standards, Methods for dilution antimicrobial susceptibility test for bacteria that grow aerobically. Approved standard, $4^{\text {th }}$ Ed., 1997, M7-A4., Wayne, Pa.

42. Wiegand, I., Hilpert, K. and Hancock, R. E. W. Agar and broth dilution methods to determine the minimal inhibitory concentration (MIC) of antimicrobial substances. Nat. Protoc. 3 (2), 163-175 (2008). 


$$
\begin{aligned}
& \text { التثييد و التحلل الحرارى و الضوئى و التقييم المضاد للميكروبات }
\end{aligned}
$$

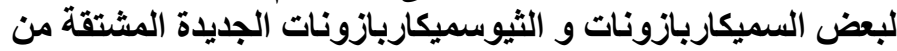

$$
\begin{aligned}
& \text { 3-مثيل-2-بنزوثيازولينون هيدرازون. }
\end{aligned}
$$

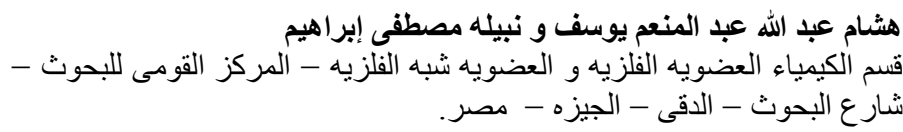

نظر اللأهمية البيولوجية لمركبات السميكاربازون و الثيوسميكاربازون وخاصة

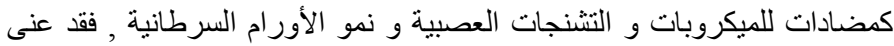

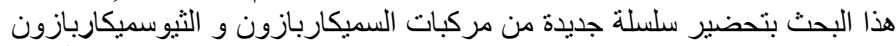
3a-j

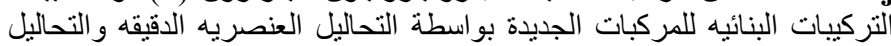

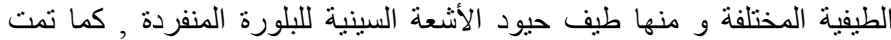

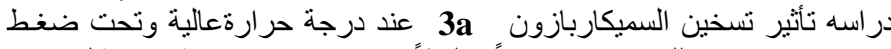

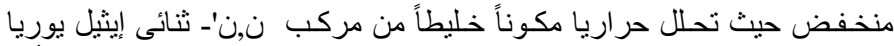

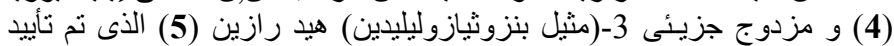

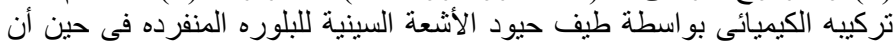

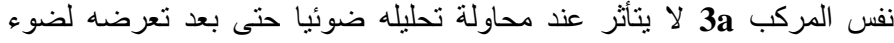

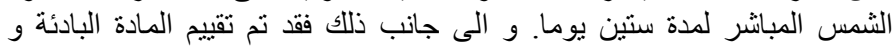

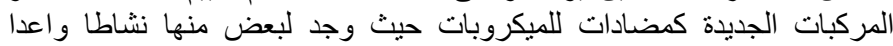

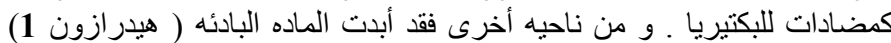

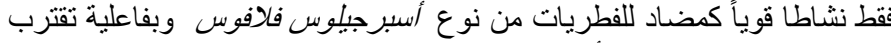

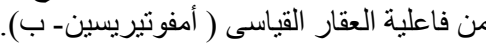

